\title{
PENGGUNAAN ANALISIS DISKRIMINAN DALAM MEMPREDIKSI PROFITABILITAS BANK PERKREDITAN RAKYAT WILAYAH DKI JAKARTA
}

\author{
Rina Dameria Napitupulu ${ }^{1)}$, David Iskandar ${ }^{2)}$ \\ Sekolah Tinggi Ilmu Ekonomi Jayakarta \\ email: ${ }^{1)}$ rinanapitupulu_dew@yahoo.com \\ 2) david_iskandar03@yahoo.com
}

\begin{abstract}
ABSTACT
This study aims to predict the profitability of rural banks domiciled in DKI Jakarta through the use of discriminant analysis. The results of this study indicate that the discriminant function formed can predict the ability of BPR profitability with an accuracy rate of $88.6 \%$. The results of the study provide practical implications for BPR management. The research implications and suggestions for further research are explained in the article.
\end{abstract}

Keywords: Rural Bank, Profitability, Discriminant Analysis

\begin{abstract}
ABSTRAK
Penelitian ini berutujuan untuk memprediksi kemampuan profitabilitas BPR yang berkedudukan di DKI Jakarta melalui penggunaan analisis diskriminan. Hasil penelitian ini menunjukkan bahwa fungsi diskriminan yang terbentuk dapat memprediksi kemampuan profitabilitas BPR dengan tingkat akurasi sebesar 88,6\%. Hasil penelitian memberikan implikasi praktis bagi pengurus BPR. Implikasi penelitian dan saran bagi penelitian selanjutnya dijelaskan dalam artikel.
\end{abstract}

Kata kunci: Bank Perkreditan Rakyat, Profitabilitas, Analisis Diskriminan

\section{PENDAHULUAN}

Ditengah ketatnya dinamika persaingan industri keuangan yang semakin berkembang pesat dewasa ini, pada akhir tahun 2017, di Indonesia tercatat bahwa jumlah Bank Perkreditan Rakyat (BPR) sebanyak 1.619 BPR, dengan total asset keseluruhan BPR mencapai Rp125.945 miliar rupiah. Jumlah Dana Pihak Ketiga (DPK) dan Kredit yang dihimpun dan disalurkan oleh BPR adalah sebesar Rp84.861 miliar rupiah dan Rp89.482 miliar rupiah pada akhir tahun 2017. BPR memiliki segmentasi penyaluran kredit kepada sektor Usaha
Mikro Kecil dan Menengah (UMKM), hal tersebut senada dengan cikal-bakal sejarah BPR yang awalnya merupakan Bank Pasar.

Di DKI Jakarta, terdapat 22 BPR yang tersebar di Jakarta Pusat, Jakarta Barat, Jakarta Timur, Jakarta Utara dan Jakarta Selatan. Total asset BPR di DKI Jakarta adalah sebesar Rp2.524 miliar dengan total kantor adalah sebanyak 52 Kantor. Keberadaan BPR di wilayah DKI Jakarta turut membantu pertumbuhan UMKM, dengan pendekatan socio cultural, prosedur yang masih relatif 
sederhana dan proses pencairan kredit yang sesuai dengan kebutuhan UMKM.

Namun tingginya persaingan yang bersifat sangat bebas menjadikan BPR bukanlah satu-satunya penyedia pembiayaan kepada UMKM. Saat ini terdapat beberapa alternatif sumber pembiayaan kepada UMKM. Subtitusi pembiayaan yang saat ini tersedia dipasar sangat beraneka ragam, contohnya adalah produk-produk pinjaman yang dapat disediakan oleh Bank Umum, Perusahaan Pembiayaan, Pegadaian, Fintech, Koperasi Simpan Pinjam, dan pembiayan lainnya. Sebagai contoh, meski sejatinya BPR merupakan mitra dari UMKM namun porsi pembiayaan BPR terhadap UMKM masih relatif kecil jika dibandingkan dengan Bank Umum (Yuliandari, 2015).

Mempertimbankan andil dan peran BPR dalam turut serta memajukan perekonomian masyarakat di DKI Jakarta, maka keberadaan BPR perlu mendapat perhatian yang lebih baik dari sebelumnya. Salah satu bentuk perhatian terhadap BPR di DKI Jakarta adalah menyoroti kemampuan profitbilitas BPR yang memiliki peranan signifikan dalam mendukung pertumbuhan industri BPR. BPR sebagai badan usaha memiliki dua tujuan, pertama, untuk memperoleh keuntungan dan kedua, untuk meningkatkan taraf hidup masyarakat melalui kegiatan intermediasai dana.
Profitabilitas adalah kemampuan perusahaan untuk menghasilkan laba selama periode tertentu (Munawir, 2010).

Secara Nasional, kemampuan profitabilitas industri BPR masih dapat digolongkan sehat, namun terdapat trend penurunan kemampuan profitabilitas yang statis dan cukup signifikan. Rasio return on asset (ROA) terus merosot dari tahun 2013 hingga 2017 berturut-turut adalah $3,44 \%, 2,98 \%, 2,71 \%, 2,59 \%$, dan $2,55 \%$. Sementara itu, rasio return on equity (ROE) tergerus selama tahun 2013 hingga 2017 berturut-turut adalah 32,41\%, $27,89 \%, 24,76 \%, 23,61 \%$, dan 23,06\% (Statistik Perbankan Indonesia, 2018). Dengan kata lain industri BPR secara nasional mengalami suatu kondisi yaitu, penurunan kemampuan profitabilitas. Terlepas dari pergerakan rasio profitabilitas yang terus anjlok, selama tahun 2006 hingga tahun 2017 tercatat sudah sebanyak 84 BPR/BPRS telah dilikuidasi oleh Lembaga Penjamin Simpanan (LPS) yang disebabkan oleh berbagai faktor.

Atas uraian tersebut, penelitian tentang profitabilitas BPR menjadi sebuah bahasan penting pada saat ini karena kemampuan profibilitas BPR merupakan faktor penentu keberlanjutan pertumbuhan industri BPR itu sendiri tidak terkecuali terhadap industri BPR di DKI Jakarta. 


\section{TINJAUAN LITERATUR}

\section{Pengertian Bank Perkreditan Rakyat} (BPR)

BPR sebagaimana diatur dalam Undang Undang Nomor 10 Tahun 1998 tentang Perubahan Atas Undang-Undang Nomor 7 Tahun 1992 Tentang Perbankan adalah Bank yang melaksanakan kegiatan usaha secara konvensional atau berdasarkan prinsip syariah yang dalam kegiatannya tidak memberikan jasa dalam lalu lintas pembayaran. BPR mempunyai fungsi sebagai Penghimpun dan penyalur dana masyarakat dan memiliki tujuan untuk menunjang pelaksanaan pembangunan nasional dalam rangka meningkatkan pemerataan, pertumbuhan ekonomi, dan stabilitas nasional ke arah peningkatan kesejahteraan rakyat banyak (Palepi, 2016). Fungsi tersebut dikenal dengan fungsi intermediasi dana, sedangkan instrumen yang dimliki oleh BPR dalam menghimpun dan menyalurkan dana adalah produk tabungan, deposito dan kredit yang diberikan (Taswan, 2010). Badan hukum BPR dapat berupa Perseroan Terbatas, Perusahaan Daerah atau Koperasi.

\section{Profitabilitas BPR}

BPR sebagaimana dimakud dalam Undang Undang tentang Perbankan adalah sebuah Badan Usaha. Sebagai badan usaha, BPR sepatutnya dapat menghasilkan laba melalui semua kemampuan dan sumber daya yang dimiliki yang dapat tercermin dalam rasio Profitabilitas (Hery, 2015). Kemampuan Profitabilitas yang baik merupakan pertahanan utama bagi BPR dalam mengantisipasi kerugian yang tidak terduga. Sebagai institusi yang berorientasi kepada profit maka kemampuan untuk mengahsilkan laba merupakan hal penting dalam kegiatan bisnis BPR.

Tujuan akhir dari sebuah perusahaan adalah untuk memperoleh laba (Aremu, et. al, 2013), Sedangkan untuk mencapai tingkat laba yang yang lebih optimal, suatu perusahaan harus memiliki proses internal yang kuat dalam mengelola aktiva dan kewajiban yang ada (Barnekow, 2012). Untuk menggambarkan kemampuan perusahaan dalam mencapai tujuannya tersebut, salah satu rasio yang dapat digunakan adalah rasio profitabilitas (Malik, 2013).

Dalam kegiatan usaha bank, rasio Profitabilitas dinilai merupakan tolak ukur yang paling tepat dalam menilai kinerja keuangan Bank (Azwan, 2016). Menurut (Ihnatov, et. al, 2015), faktor-faktor yang memengaruhi kemampuan profitabilitas bank secara umum dikelompokkan kedalam dua jenis yaitu faktor internal (bank specific) dan ekternal bank (industry specific and macro economics). Faktor internal bank terdiri dari ukuran bank 
(bank size), risiko kredit (credit risk), risiko likuiditas (liquidity risk), efisiensi manajemen (management efficiency), kecukupan modal (capital adequacy) dan bauran bisnis bank (business mix), sedangkan faktor ekternal bank terdiri dari inflasi, pertumbuhan ekonomi, banking system concentration dan lain-lain.

Salah satu indikator yang dapat mencerminkan kemampuan profitabilitas bank adalah rasio return on asset. (Nurbaiti, et. al, 2017). Dalam regulasi $\mathrm{BPR}$, rasio ROA adalah perbandingan jumlah laba sebelum pajak dengan ratarata total asset BPR dalam satu periode. Rasio ROA merupakan salah satu indikator dalam kerangka menghitung tingkat kesehatan BPR. Suatu BPR dapat dikatakan memiliki kemampuan profitbilitas yang sehat apabila memiliki rasio $\mathrm{ROA}>1,5 \%$ (Alifah, 2014).

\section{Penelitian Terdahulu}

Penelitian ini beranjak dari beberapa penelitian terdahulu yang memiliki perhatian kepada profitabilitas BPR. Kesamaan beberapa studi mengenai profitabilitas BPR pada masa lalu adalah fokus untuk meneliti faktor-faktor yang berpengaruh terhadap profitabilitas. Namun belum banyak dijumpai studi yang menitikberatkan terhadap prediksi kemampuan profitabilitas BPR. Beberapa penelitian tentang Profitabilitas BPR adalah sebagai berikut:

(Masdjojo, et. al, 2018) melakukan studi untuk menganalisis pengaruh kredit bermasalah, posisi kredit, tingkat Efisien dan Kemampuan Modal terhadap Profitabilitas BPR. Data dianalisis dengan metode analisis regresi data panel dengan estimasi Fixed Effect (FEM) dan Random Effect (REM). Kesimpulan yang ditarik dari hasil studi tersebut adalah bahwa Kredit Bermasalah, Tingkat Efisiensi dan Kemampuan Modal berpengaruh negatif dan signifikan terhadap Profitabilitas. Sedangkan Porsi Kredit berpengaruh positif dan tidak signifikan.

(Suryantini, et. al, 2018) melakukan riset mengenai pengaruh dari risiko likuiditas, risiko kredit, dan risiko operasional terhadap profitabilitas BPR di Kota Denpasar. Keseimpulan penelitian tersebut bahwa risiko likuiditas yang diwakili oleh LDR memiliki pengaruh positif signifikan terhadap profitabilitas, risiko kredit yang diwakili oleh NPL memiliki pengaruh negatif signifikan terhadap profitabilitas, dan risiko operasional yang diwakili oleh BOPO memiliki pengaruh negatif signifikan terhadap profitabilitas. Risiko likuiditas, risiko kredit, dan risiko operasional secara signifikan mempengaruhi profitabilitas sebesar $59,4 \%$.

(Suardikha, et. al, 2015) meneliti tingkat perputaran kredit, tingkat perputaran kas, dan pertumbuhan jumlah nasabah kredit pada profitabilitas di BPR Kabupaten Gianyar. Hasil analisis 
penelitian yang didapatkan adalah bahwa tingkat perputaran kredit dan pertumbuhan jumlah nasabah kredit berpengaruh positif secara parsial terhadap profitabilitas pada BPR di Kabupaten Gianyar periode 20102012 sedangkan perputaran kas tidak berpengaruh secara parsial terhadap profitabilitas pada BPR di Kabupaten Gianyar.

(Pandoyo, 2019) melakukan studi dengan tujuan untuk mengestimasi pengaruh CAR, LDR, BOPO, dan NPL terhadap profitabilitas (ROA) pada BPR di Provinsi Jawa Barat periode 2012 - 2016. Data dikumpulkan dari data sekunder dan analisis data menggunakan regresi linier berganda. Hasil penelitian memberikan bukti bahwa: hanya BOPO yang terbukti berpengaruh signifikan terhadap ROA. Sedangkan variabel lain yaitu CAR dan NPL berpengaruh positif namun tidak signifikan, dan NPL berpengaruh negatif namun tidak signifikan terhadap ROA.

Sedangkan untuk prediksi kebangkrutan bank, (Iswadi, 2015) melakukan studi prediksi kebangkrutan terhadap BPRS (Bank Pembiayaan Rakyat Syariah) di Sumatera Tengah dengan menggunakan model kebangrutan Altman Z-Score. Hasil studi tersebut adalah tidak ada BPRS di Sumatera Tengah yang berada pada zona aman, Terdapat 8 BPRS yang berada pada grey area dan terdapat 2 BPRS yang berpotensi bangkrut.

\section{METODOLOGI}

Pendekatan metodologi yang digunakan dalam penelitian ini adalah metode diskriminan. Dalam metode diskriman terdapat dua jenis kelompok yaitu, metode diskriminan dengan dua kategori dan metode diskriminan dengan lebih dari dua kategori, metode diskriminan dengan dua kategori disebut Two-Group Discriminant Analysis sedangkan metode diskriminan dengan lebih dari dua kategori disebut Multiple Discriminant Analysis (Widarjono, 2015). Penelitian ini termasuk kedalam jenis metode diskriminan Two-Group Discriminant Analysis.

Terdapat dua metode estimasi dalam analisis diskriminan, yaitu metode estimasi secara menyeluruh (simultaneous or direct method) dan metode estimasi secara bertahap (stepwise method). Metode estimasi secara menyeluruh atau simultan adalah metode dalam menghitung fungsi diskriminan, sehingga semua variabel independen yang ada dipertimbangkan secara bersamaan, dengan menggunakan metode ini fungsi diskriminan dicari berdasarkan pada semua variabel independen tanpa memandang kekuatan diskriminasi dari setiap variabel independen. Sedangkan dalam metode estimasi secara bertahap (stepwise), secara otomatis metode ini menyeleksi hanya 
kepada variabel-variabel independen yang mampu memaksimumkan diskriminasi antar kelompok dengan baik. Dengan kata lain, hanya variabel independen yang mampu melakukan diskriminasi atanra kelompok dengan baik yang kemudian dimasukkan kedalam fungsi diskriminan sedangkan variabel independen yang tidak mampu melakukan diskriminasi dihilangkan di dalam fungsi diskriminan (Widarjono: 2015). Metode estimasi yang digunakan dalam penelitian ini adalah metode estimasi secara bertahap (stepwise).

Penelitian ini menggunakan data populasi seluruh BPR konvensional yang berkedudukan di DKI Jakarta Periode tahun 2016 dan tahun 2017.

\section{Operasionalisasi Variabel}

Sebagai variabel independen, dipilih beberapa rasio yang relevan dengan kegiatan usaha bank yang didasarkan oleh beberapa teori rasio modal, yaitu ukuran yang menunjukkan tingkat keberadaan jumlah modal tertentu untuk melindungi deposan, menutup kerugian demi menjaga going concern bank, membeli aktiva tetap demi kelancaran layanan jasa bank, dan memenuhi ketentuan pihak regulator demi menjaga ekspansi aktiva yang tidak dibenarkan (Hempel, 1994), diantaranya adalah:
$\mathrm{X}_{1}$ : Capital to total deposit (CTD), yaitu total modal bank dibagi dengan jumlah total dana pihak ketiga.

$\mathrm{X}_{2}$ : Equity to total deposit (ETD), yaitu total ekuitas bank dibagi dengan total dana pihak ketiga.

$\mathrm{X}_{3}$ : Loans to Equity (LTE), yaitu total kredit dibagi dengan total ekuitas bank.

$\mathrm{X}_{4}$ : Loans to Capital (LTC), yaitu total kredit dibagi dengan total modal bank. $\mathrm{X}_{5}$ : Fixed asset to equity (FAE), yaitu total aset tetap dibagi dengan total ekuitas bank.

$\mathrm{X}_{6}$ : Fixed asset to capital (FAC), yaitu total aset tetap dibagi dengan total ekuitas bank.

Kemudian ditambahkan dengan variabel rasio-rasio risiko keuangan yaitu ukuran yang menunjukkan tingkat relatif atas konsekuensi pengambilan keputusan manajemen dalam berbagai dimensi keuangan guna mencapai return yang diinginkan. Return yang tinggi biasanya hanya mungkin dicapai dengan mengambil risiko yang tinggi pula, dan sebaliknya (Short et al., 1985; Fraser \& Fraser, 1990;30 dan Hempel et. al, 1994: 68 dan 272 dalam Hadad, et. al: 2004) di antaranya terdiri dari

X7 : Loan to Asset Risk (LAR), yaitu total kredit dibagi dengan total asset bank.

X8 : Liquidity Risk (LR), yaitu total asset lancar setelah dikurangi oleh 
kewajiban lancar dibagi dengan total asset bank.

X9 : Equity to risk asset (ERA), yaitu total ekuitas bank dibagi dengan asset berisiko (total asset dikurangi dengan kas dan penempatan Sertipikat Bank Indonesia).

X10: Deposit Risk (DR), yaitu total ekuitas dibagi dengan total dana pihak ketiga.

X11: Capital to Asset Risk (CAPAR), yaitu total modal bank dibagi dengan total asset bank.

Sesuai dengan ciri khusus karakterisitik analisis diskriminan, yaitu variabel dependen harus berupa data kategori atau nonmetric (Ghozali, 2006). Variabel dependen dalam penelitian ini adalah: $0=$ "BPR Rugi", dan $1=$ "BPR Laba".

\section{HASIL DAN PEMBAHASAN}

\section{Hasil Estimasi Stepwise Method}

Berdasarkan metode Two-Group Discriminant Analysis, didapatkan hasil stepwise method, dengan lima peubah yang signifikan membedakan BPR rugi dan BPR laba. Lima variabel tersebut adalah $\mathrm{X}_{3}$ (loan to equity); $\mathrm{X}_{11}$ (capital to asset risk); $\mathrm{X}_{9}$ (equity to risk asset); $\mathrm{X}_{4}$ (loan to capital); dan $\mathrm{X}_{6}$ (fix asset to equity).

Tabel 1

Hasil Analisis Stepwise

\begin{tabular}{|c|c|c|c|c|c|c|c|c|}
\hline \multirow[b]{3}{*}{ Step } & \multirow[b]{3}{*}{ Entered } & \multicolumn{7}{|c|}{ hatks' Lambda } \\
\hline & & \multirow[b]{2}{*}{ Statistic } & \multirow[b]{2}{*}{ df1 } & \multirow[b]{2}{*}{ dff } & \multirow[b]{2}{*}{$d f 3$} & \multicolumn{3}{|c|}{ Exast $F$} \\
\hline & & & & & & Statistic & dif & df2 \\
\hline 1 & LTE & 803 & 1 & 1 & 42000 & 10.290 & 1 & 42.000 \\
\hline 2 & CAPAR & 571 & 2 & 1 & 42000 & 15.425 & 2 & 41.000 \\
\hline 9 & ERA & 451 & g & 1 & 42000 & 17.610 & $\mathrm{~s}$ & 40.000 \\
\hline 4 & LTC & 591 & 4 & 1 & 42000 & 15.194 & 4 & 39.000 \\
\hline 5 & FAB & 351 & 5 & 1 & 42000 & 14.036 & 5 & 38.000 \\
\hline
\end{tabular}

2. Hasil Canonical Discriminant Function Coefficients

Selanjutnya lima peubah tersebut terpilih untuk dimasukkan ke dalam fungsi diskriminan. Dan fungsi diskriminan yang terbentuk adalah sebagai berikut:

$$
\begin{gathered}
Y=-0,288+0,16\left(X_{3}\right)-0,47\left(X_{4}\right)- \\
2,183\left(X_{6}\right)-4,750\left(X_{9}\right)+5,955\left(X_{11}\right)
\end{gathered}
$$

Tabel canonical discriminant function coefficients menerangkan model diskriminan yang terbentuk dari hasil penelitian ini.

Tabel 2

Fungsi Diskriminan

Canonical Discriminant Function

Coefficients

\begin{tabular}{|l|r|}
\hline \multirow{2}{*}{} & \multicolumn{1}{|c|}{ Function } \\
\cline { 2 - 2 } & 1 \\
\hline LTE & .160 \\
LTC & -.047 \\
FAE & -2.183 \\
\hline ERA & -4.750 \\
CAPAR & 5.955 \\
(Constant) & -288 \\
\hline
\end{tabular}

\section{Unstandardized coefficients}

3. Hasil Summary of Canonical Discriminant

Nilai akar ciri yang didapat dalam penelitian ini adalah diatas 0,05, yaitu sebesar 0,805. Dengan kata lain, fungsi diskriminan yang terbentuk cukup baik karena tidak terjadi multikolinearitas di antara sesama peubah bebasnya.

\section{Tabel 3}


Hasil Summary of Canonical Discriminant

\begin{tabular}{|l|r|r|r|r|}
\hline Function & Eigenvilue & $\%$ of Variance & Currulative \% & $\begin{array}{l}\text { Cononical } \\
\text { Correlation }\end{array}$ \\
\hline 1 & $1.847^{\mathrm{a}}$ & 100.0 & 100.0 & .805 \\
\hline
\end{tabular}

a. First 1 canonical discriminant functions were used in the analysis.

\section{Hasil Function at Group Centroid}

Group Centroid merupakan ratarata nilai fungsi diskriminan dari tiap-tiap observasi di dalam masing-masing kelompok. Berdasarkan hasil analisa function at group centroid, Group Centroid untuk kelompok BPR rugi adalah 1,673 dan untuk BPR laba adalah -1,054. Bahwa secara rata-rata skor diskriminan kedua kelompok berbeda cukup besar. Sehingga fungsi diskriminan yang diperoleh dapat membedakan secara baik kelompok yang ada.

\section{Tabel 4}

Function at Group Centroid

\begin{tabular}{|l|c|}
\hline \multirow{2}{*}{ USAHA BPR } & Function \\
\cline { 2 - 2 } & \multicolumn{1}{|c|}{1} \\
\hline BPR RUGI & 1.673 \\
BPR LABA & -1.054 \\
\hline
\end{tabular}

Unstandardized canonical discriminant functions evaluated at group means

\section{Penentuan Cut Off Score}

Nilai kritis atau pisah batas (cut off score) dalam analisis diskriminan diperoleh dengan menggunakan rumus (Ghozali, 2006):

$$
Z_{C U}=\frac{N_{A} Z_{B}+N_{B} Z_{A}}{N_{A}+N_{B}}
$$

keterangan:
$\mathrm{Z}_{\mathrm{CU}}=$ Angka Kritis, berfungsi sebagai $c u t$ off score.

$\mathrm{N}_{\mathrm{A}}=$ Jumlah anggota grup A (BPR Rugi)

$\mathrm{N}_{\mathrm{B}}=$ Jumlah anggota grup B (BPR Laba)

$\mathrm{Z}_{\mathrm{A}}=$ Angka centroid pada grup A (BPR Rugi)

$\mathrm{Z}_{\mathrm{B}} \quad=$ Angka centroid pada grup $\mathrm{B}(\mathrm{BPR}$ Laba)

Sehingga perhitungan angka kritis dalam penelitian adalah sebagai berikut:

Tabel 5

Prior Probabilities for Groups

\begin{tabular}{|l|r|r|r|}
\hline \multirow{2}{*}{ USAHA_BPR } & \multirow{2}{*}{ Frior } & \multicolumn{2}{|c|}{ Cases Used in Analysis } \\
\cline { 3 - 4 } & \multicolumn{1}{|c|}{ Unweighted } & Weighted \\
\hline BPR RUGI & .500 & 17 & 17.000 \\
BPR LABA & .500 & 27 & 27.000 \\
Total & 1.000 & 44 & 44.000 \\
\hline
\end{tabular}

Dari tabel prior probabilities for groups tersebut diatas didapatkan bahwa jumlah anggota $\mathrm{N}_{\mathrm{A}}$ (BPR Rugi) adalah 17, dan jumlah anggota $\mathrm{N}_{\mathrm{B}}$ (BPR Laba) adalah 27. Sedangkan nilai centroid yang terdapat dalam Tabel 4 adalah $\mathrm{Z}_{\mathrm{A}}=1,673$ dan $\mathrm{Z}_{\mathrm{B}}=$ -1,054. Sehingga penentuan cut off score:

$$
\begin{gathered}
\frac{(17 \times(-1,054))+(27 \times 1,673)}{17+27} \\
=0,6194
\end{gathered}
$$

Dengan kata lain, jika menggunakan fungsi diskriminan yang terbentuk dalam penelitian ini dan menggunakan acuan cut off score $\mathrm{Z}_{\mathrm{CU}}$ sebesar 0,6194 maka dapat disimpulkan apabila terdapat perhitungan hasil fungsi diskriminan lebih tinggi dari nilai $\mathrm{Z}_{\mathrm{CU}}$, maka dapat digolongkan masuk kedalam kelompok BPR Rugi (kode 0) dan 
sebaliknya apabila terdapat perhitungan hasil fungsi diskriminan lebih rendah dari nilai $\mathrm{Z}_{\mathrm{CU}}$, maka dapat digolongkan masuk kedalam kelompok BPR Laba (kode 1).

\section{Hasil Keakuratan Prediksi Model Diskriminan}

Tabel 6

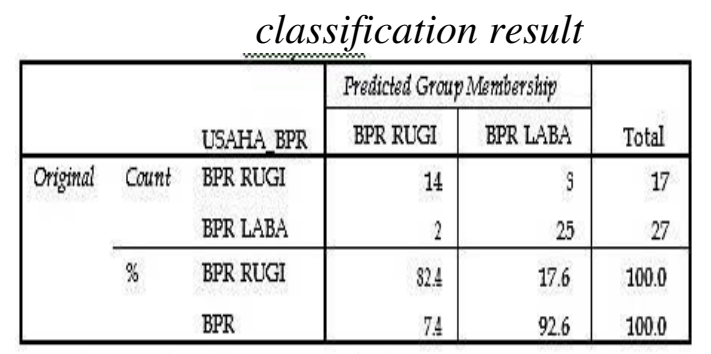

a. $88.6 \%$ of original grouped cases correctly classified.

Dalam tabel classification result didapatkan perbandingan antara hasil prediksi model diskriminan dengan kondisi sesungguhnya dari populasi yang diteliti yang bertujuan untuk mengukur sejauh mana tingkat akurasi prediksi dari fungsi diskriminan yang terbentuk. Dalam hasil tersebut dapat disimpulkan bahwa model diskriminan memiliki tingkat akurasi prediksi sebesar 88,6\% dengan kesalahan prediksi sebanyak 5 data. Yaitu, 3 data yang seharusnya berada dalam kategori BPR Rugi digolongkan masuk kedalam kategori BPR laba dan 2 data yang seharusnya berada dalam kategori BPR Laba digolongkan masuk kedalam kategori BPR Rugi oleh model diskriminan.

\section{IMPLIKASI / KESIMPULAN DAN SARAN}

1. Kesimpulan
Metoda analisis diskriminan yang terbentuk dalam penelitian ini dapat dijadikan suatu predictive model dalam memprediksi dan memberikan gambaran mengenai kemampuan profitabilitas BPR dimasa yang akan datang.

\section{Saran}

Profitabilitas BPR merupakan cerminan dari seluruh upaya dan tindakan maupun kinerja manajemen dalam suatu periode tertentu. Model prediksi dalam penilitian ini dapat mengakomodir dan mengolah data-data yang bersifat kuantitatif dari hasil publikasi laporan keuangan BPR. Namun disamping itu, penelitian ini terbatas kepada asumsiasumsi statistika dan informasi-informasi yang bersifat kualitatif sehingga tidak mungkin dapat mengakomodir secara penuh kebutuhan dalam melakukan perkiraan kemampuan profitabilitas BPR seutuhnya. Penggunaan predictive model dalam penelitian ini dapat disandingkan dengan informasi lain sehingga pengguna mendapatkan gambaran lebih luas tentang kemampuan profitabilitas BPR. Sedangkan untuk penelitian selanjutnya dapat mempertimbangkan faktor-faktor lain seperti tingkat kesehatan BPR, kualitas tata kelola BPR dan penerapan Manajemen Risiko BPR.

Untuk mengantisipasi kerugian yang mungkin dialami oleh BPR, secara 
khusus pengurus BPR harus memberikan perhatian lebih terhadap kemampuan profitabilitas. Langkah-langkah antisipatif perlu diambil oleh pengurus BPR, seperti: menjaga going concern BPR dengan menerapkan praktek kegiatan perbankan berasaskan prinsip kehati-hatian (prudential banking), menigkatkan permodalan BPR, melakukan inovasi terhadap bisnis proses BPR dan memasitikan kecukupan dan kehandalan sumber daya manusia yang dimiliki oleh BPR.

\section{Implikasi}

Fungsi diskriminan yang terbentuk dalam penelitian ini merupakan predictive model yang dapat menjadi acuan pelengkap bagi stakeholder BPR, yaitu pemegang saham, pengurus BPR, deposan, debitur dan masyarakat luas dalam melakukan evaluasi terhadap BPR. Disamping itu, pengurus BPR dapat mendayagunakan penelitian ini dalam rangka mengoptimalkan kegiatan usaha BPR denagn meningkatkan kemampuan profitabilitas BPR sekaligus sebagai suatu alat early warning system untuk mengantisipasi kemungkinankemungkinan yang berakibat buruk terhadap perolehan profit BPR agar dapat secara dini menentukan langkah-langkah strategis yang perlu dialmbil oleh manajemen dengan mempertimbangkan faktor-faktor yang belum dapat diakomodir dalam model prediksi diskriminan pada penelitian ini.

\section{REFERENSI}

Agus, Widarjono. 2015. Analisis Multivariat Terapan. Yogyakarta : Penerbit UPP STIM YKPN.

Alifah. 2014. "Pengaruh CAR, NPL, BOPO, dan LDR Terhadap Profitabilitas Bank (ROA) pada Perusahaan Perbankan yang Terdaftar di Bursa Efek Indonesia Periode 2009-2012”. Fakultas Ekonomi Universitas Negeri Yogyakarta.

Aremu, Mukaila Ayanda, Imoh Christopher and Dr. Mustapha Adeniyi Mudashiru. 2013. "Determinants of Bank's Profitability in a developing Economy: Evidence From Nigerian Banking Industry". Journal of Contemporary Research in Business. 4(9): h: 155-181.

Azizah1, Istiqomah dan. Masdjojo, Gregorius N. 2018. "Pengaruh Kredit Bermasalah, Porsi Kredit, Tingkat Efisiensi, Dan Kemampuan Modal Terhadap Rofitabilitas Pada Bank Perkreditan Rakyat Di Sumatera Barat Periode 2013-2016”. Proceeding SENDI_U: Universitas Unisbank.

Barnekow, Sabine. 2012. "Jenepotik Pos a Succesful 1st Half-Year and Anticipates Growth in Sales and Earnings for the Full Year 201". Targeted News Service Newspaper: Washington D.C., United States.

Elvira Azwan, A. H. 2016. "Analisis Faktor-Faktor yang Mempengaruhi Kinerja Profitabilitas Bank Perkreditan 
Rakyat Konvensional di Provinsi Riau dengan Efisiensi Sebagai Faktor Pemoderasi”. Jurnal Tepak Manajemen Bisnis, VIII (2), 310-321.

Ghozali, Imam. 2006. Aplikasi Analisis Multivariate Dengan Program SPSS. Semarang: Universitas Diponegoro Semarang.

Hery. 2015. "Analisis Laporan Keuangan”. Yogyakarta: CAPS.

Iswadi, Tony. 2017. "Analisa Kinerja Keuangan Dan Prediksi Kebankrutan Bank Pembiayaan Rakyat Syariah”. Jurnal Lembaga Keuangan dan Perbankan Fakultas Ekonomi dan Bisnis Islam Universitas Islam Negeri Imam Bonjol Padang Vol.2, No.1.

Lokollo, Antonius, dan Muchamad Syarifudin. 2013. "Pengaruh Manajemen Modal Kerja dan Rasio Keuangan terhadap probabilitas pada industri manufaktur yang terdaftar di Bursa Efek Indonesia Tahun 2011". Diponegoro Journal of Accounting, Vol. 2, No. 2, Hlm. $1-13$.

Margaretha, F., \& Zai, M. P. 2013. "Faktor-faktor yang mempengaruhi Kinerja Keuangan Perbankan Indonesia”. Jurnal Bisnis dan Akuntansi ISSN 14109875, 133-141.

Munawir, S. 2010. "Analisa Laporan Keuangan Edisi Keempat". Liberty: Yogyakarta

N.C, Pratiwi, Kadek dan Suryantini, N.P Santi. 2018. "Pengaruh Risiko Bank Terhadap Profitabilitas Bank BPR Di Kota Denpasar". Jurnal Manajemen, [S.1.], v. 7, n. 7 , p. $3886-3914$.

Nurbaiti, et. al. 2017. “Analisis FaktorFaktor Yang Mempengaruhi Tingkat Profitabilitas Industri Perbankan (Studi Pada Bank Bumn Yang Terdaftar Di Bursa Efek Indonesia Periode Penelitian 2008-
2015)". EProccedings of Management Telkom University. Vol. 4, No.2

Otoritas Jasa Keuangan. 2018. "Statistik Perbankan Indonesia”. Jakarta

Palepi, 2016. "Analisis CAR/KPMM, LDR, dan NPL Serta Pengaruhnya Terhadap ROA PT.BPR Sindang Binaharta Periode 2011-2015”. Jurnal Media Ekonomi. 1-17.

Pandoyo. 2019. "Faktor-Faktor Yang Mempengaruhi Profitabilitas Bank BPR Di Provinsi Jawa Barat". Jurnal Riset Manajemen dan Bisnis (JRMB) Fakultas Ekonomi UNIAT Vol.4, No.1 Februari 2019: 127 - 136 .

Petria, N., Capraru, B., \& Ihnatov, I. 2015. 'Determinants of Banks' Profitability: Evidence from EU 27 Banking Systems". Procedia Economics and Finance, 20(15), 518-524.

Raheem Anser, Qaisar Ali Malik. 2013. "Cash Conversion Cycle and Firms' Profitability - A Study of Listed Manufacturing Companies of Pakistan". Journal of Business and Management. 8(2): h: $83-87$

Taswan. 2010. "Manajemen Perbankan: Konsep, Teknik dan Aplikasi (Edisi II)". Yogyakarta: UPP STIM YKPN.

Widyastuti, Indria dan Yuliandari, Dewi. 2016. “Analisis Peran Bank Perkreditan Rakyat (Bpr) Terhadap Peningkatan Kinerja Usaha Mikro Kecil (UMK)". Jurnal Humaniora Universitas Bina Sarana Informatika. Vol. 16, No.2

Undang Undang Nomor 10 Tahun 1998 tentang Perubahan Atas Undang-Undang Nomor 7 Tahun 1992 Tentang Perbankan. 